\title{
DEPÓSITOS DE VERTENTE E EVOLUÇÃO QUATERNÁRIA DO PLANALTO DO ITATIAIA
}

\author{
May Christine MODENESI
}

\begin{abstract}
RESUMO
Nas médias e baixas encostas do vale dos Lírios e em alvéolos menores da bacia do ribeirão das Flores, encontram-se depósitos correlativos da evolução quaternária do planalto do Itatiaia. Os processos responsáveis pela deposição dos tálus suspensos, concentrações lineares de matacões, depósitos de seixos angulosos e duas gerações de colúvios refletem influências de reativação tectônica e de variações climáticas pleistoceno-holocênicas. Eventos mais antigos e eficientes na liberação de blocos e matacões das vertentes rochosas íngremes - explicados por um conjunto de ações de amplo espectro, que incluiria processos de gelivação - teriam dado lugar a episódios de coluvionamento. Colúvios $\mathrm{C}_{\mathrm{I}}$ heterométricos, com blocos do regolito, e colúvios $\mathrm{C}_{\mathrm{II}}$ mais homogêneos e finos, com pequenos seixos e grânulos, resultariam da ação de processos cada vez menos agressivos, capazes de retrabalhar apenas os produtos de fases erosivas anteriores. A diminuição da atividade denudacional nas encostas do planalto favoreceu o preenchimento das várzeas e depressões hidromórficas, com sedimentos holocênicos relativamente finos, e a formação de turfeiras.
\end{abstract}

\begin{abstract}
Correlative deposits found on the middle and lower hillslope sectors of the plateau document the Quaternary evolution of the Itatiaia plateau. Hanging talus cones, linear concentrations of boulders, screes and two colluvium generations reflect processes related to tectonic reactivation and climatic changes. Older events, more efficient in detaching blocks and boulders from free faces - associated to a group of processes including frost action - would have been replaced by colluviation episodes. Heterometric $C_{I}$ colluvia with bedrock clasts and $\mathrm{C}_{\mathrm{II}}$ sequences with fewer and smaller clasts would indicate the action of processes capable only of reworking materials freed by previous erosional phases. Decrease in intensity of slope denudation favored the filling of floodplains and hydromorphic depressions with relatively fine Holocene sediments, as well as the formation of tropical altitude peatbogs.
\end{abstract}

\section{INTRODUÇÃO}

O planalto do Itatiaia corresponde à área de menor amplitude de relevo situada no topo do maciço alcalino, a $2.300-2.500 \mathrm{~m}$. Entretanto, apesar de consagrado pelo uso, o termo " planalto" não define bem a realidade do relevo, caracterizado por morros de encostas abruptas e picos rochosos (Foto 1) - no centro do planalto (Agulhas Negras $2.787 \mathrm{~m}$, Pedra do Altar $2.661 \mathrm{~m}$ ) ou nas suas bordas (Pedra do Couto $2.682 \mathrm{~m}$, Prateleiras $2.515 \mathrm{~m}$ ) - que contrastam com setores planos ocupados por várzeas turfosas (ribeirão das Flores, rios Aiuruoca e Preto). A noroeste, norte, nordeste e este o planalto é limitado por um anel morfológico externo quase contínuo, que desaparece apenas em parte do setor oeste (TEIXEIRA, 1961 e PENALVA, 1967). A borda sudoeste é marcada pela escarpa Pedra do Couto-Prateleiras. No setor sul, a grande estrutura anelar sofreu um abatimento da ordem de 500m (PENALVA, 1967).
O corpo alcalino do Itatiaia, com área aproximada de $220 \mathrm{~km}^{2}$, alonga-se na direção NWSE. Limitado por gnaisses, é constituído por nefelina-sienitos, quartzo-sienitos, brechas magmáticas e granito alcalino. Os teores de quartzo destas rochas aumentam da periferia para o centro da intrusão, onde se localizam os cumes do planalto, sobre nordmarkitos e quartzo-sienitos (PENALVA, 1967 e RIBEIRO FILHO, 1967).

Os aspectos gerais do relevo do maciço do Itatiaia refletem forte influência estrutural. Estruturas anelares, a zona relativamente deprimida do planalto e fragmentos de estruturas arqueadas de menor raio - presentes no interior do grande anel externo - seriam explicados (PENALVA, 1967) pelo abatimento do topo do corpo alcalino, por falhas circulares contemporâneas da intrusão, no Cretáceo Superior (AMARAL et al., 1967; LAUAR, 1988). A rede de drenagem ajusta-se às estruturas com um padrão radial, composto pelo alto curso dos rios 


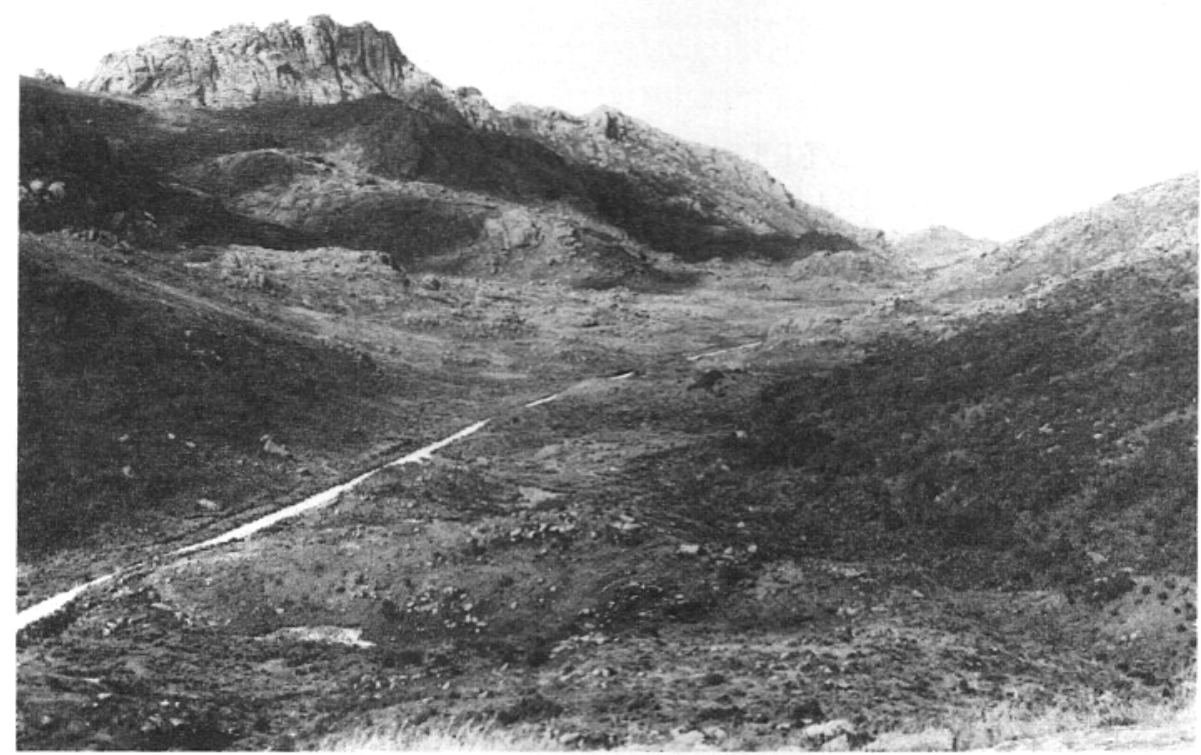

FOTO 1 - Vale dos Lírios e ribeirão das Flores a montante do Abrigo Rebouças. Ao fundo, o pico das Agulhas Negras. Vertentes rochosas íngremes e em rampa. Campos de altitude, mais ou menos arbustivos. À esquerda, na parte basal de anfiteatro, vegetação densa com árvores anãs.

Aiuruoca, Preto, Campo Belo e Itatiaia (AB'SÁBER \& BERNARDES, 1958 e TEIXEIRA, 1961). Estes rios abrem profundos boqueirões no anel morfológico externo e boqueirões menores nos anéis interiores (TEIXEIRA, 1961). Direções relacionadas ao segundo estágio tectônico da evolução do Sistema de Rifts da Serra do Mar (RICCOMINI, 1989) são particularmente nítidas no Itatiaia. Por exemplo, o ribeirão das Flores (Figuras 1 e 2, Foto 1) corta o planalto segundo a direção principal W-WNW; direções secundárias N-NNE e N-NNW podem ser reconhecidas nos seus afluentes e em outros rios do planalto. Planícies alveolares e depressões ocorrem no cruzamento de linhas de fraqueza: contatos litológicos, diaclasamentos ou falhas.

As feições menores do relevo também são condicionadas pelas estruturas. Direções de diaclasamento e mergulhos determinam forma e declividade das vertentes. Encostas escarpadas correspondem a mergulhos acentuados (60 a $\left.80^{\circ}\right)$, relacionados à direção principal e à direção N-NNW. Vertentes menos íngremes, em rampas (Foto 1) e patamares, ajustam-se com freqüência aos mergulhos menores $\left(40 \mathrm{a} 45^{\circ}\right)$, associados às direções N-NNE. Nas vertentes rochosas, afloramentos, caneluras e canais pluviais das cabeceiras de drenagem seguem a orientação dos sistemas de fraturas das alcalinas supersaturadas do planalto.

$\mathrm{Na}$ borda do planalto, o curso superior do rio Preto, ajustado ao anel externo, apresenta anomalias de drenagem - observadas nas fotos aéreas como escoamento indeciso com prováveis capturas, meandros e pequenos lagos - indicativas de tectonismo recente.

Nos cumes da Mantiqueira Oriental, mais de $2.000 \mathrm{~m}$ acima das baixas colinas do vale do Paraíba, o planalto do Itatiaia possui paisagem de montanha tropical nitidamente diferenciada das paisagens do "domínio morfoclimático dos mares de morros"' (AB'SÁBER, 1966) no qual se insere. Como lembrou DE MARTONNE (1940), o Itatiaia é o único batólito alcalino alçado a semelhantes altitudes. Substrato alcalino, formas de relevo, condições climáticas e quadro fitogeográfico combinam-se para acentuar a originalidade deste enclave de altitude.

Temperaturas médias anuais de $11,5^{\circ} \mathrm{C}$ evidenciam a influência da altitude no clima do planalto (Estação Alto do Itatiaia - Departamento Nacional de Meteorologia - $22^{\circ} 25^{\prime} \mathrm{S} / 44^{\circ} 50^{\prime} \mathrm{W}$, altitude $2.199 \mathrm{~m}$ ). Médias mensais mais elevadas ocorrem de dezembro a março e principalmente em fevereiro, o mês mais quente (média das máximas $16,8^{\circ} \mathrm{C}$ ); entretanto, as máximas absolutas são registradas em outubro $\left(24^{\circ} \mathrm{C}\right)$. $\mathrm{O}$ mês mais frio é julho (média das mínimas $4.9^{\circ} \mathrm{C}$ ), mas temperaturas inferiores a $0^{\circ} \mathrm{C}$ são comuns de maio a setembro. A mínima absoluta nos 28 anos de observação (1923-1950) é de $-5^{\circ} \mathrm{C}$. Geadas não são registradas apenas nos três primeiros meses do ano. Vinte e dois anos apresentam mais de 40 dias de geada/ano, com ocorrência máxima de 171 dias e mínima de 18 dias de geada/ano. No inverno, a freqüente queda da temperatura abaixo de $0^{\circ} \mathrm{C}$ provoca a formação de cristais aciculares de gelo na superfície úmida 


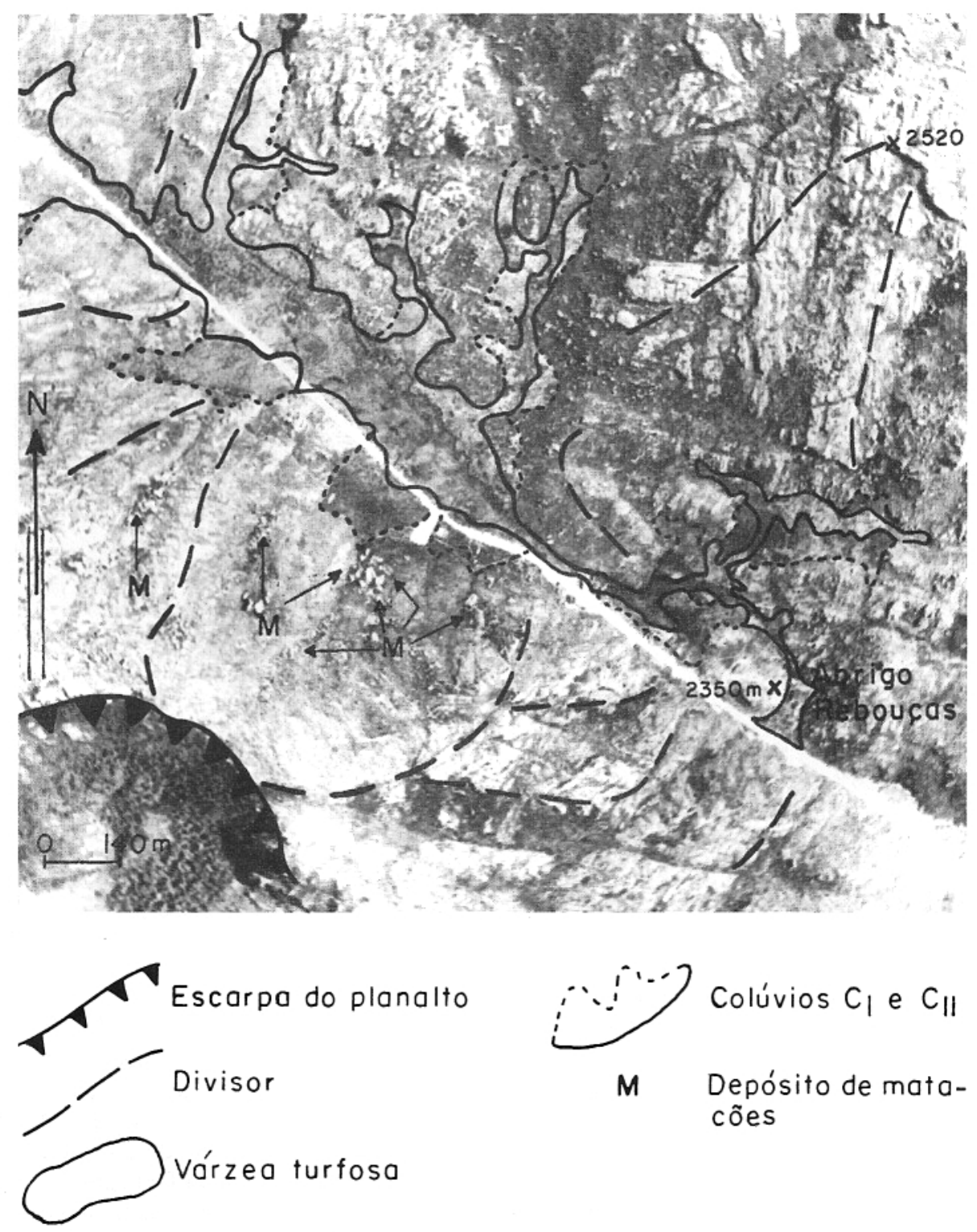

FIGURA 1 - Várzeas turfosas e depósitos de vertente do alto vale do ribeirão das Flores.

do solo ( $7 \mathrm{~mm}$ de altura) e crostas em poças d'água (mais de $1 \mathrm{~mm}$ de espessura). Nas vertentes sombrias o gelo pode permanecer durante todo o dia.

Os totais anuais de precipitação variam de $1.967 \mathrm{~mm}$ a $3.037 \mathrm{~mm}$, com média de $2.429 \mathrm{~mm}$. Oitenta por cento das chuvas concentram-se de outubro a abril. A diminuição da pluviosidade é significativa nos meses mais frios - junho $(44,9 \mathrm{~mm})$, julho $(33,8 \mathrm{~mm})$ e agosto $(45,4 \mathrm{~mm})$ - e, apesar de não definir uma estação seca, é responsável por acentuada queda do nível de cobertura dos campos, de 80 para $10 \%$ (SEGADAS-VIANA, 1965). Não houve queda de neve no período 1923-1950, mas nevadas esporá- dicas têm sido registradas (SEGADASVIANA, 1965), a última em 1985.

A vegetação expressa de modo marcante a singularidade da posição do planalto, situado acima dos limites das florestas tropicais. Campos de altitude de estrutura estépica (SEGADASVIANA, 1965), constituídos por elementos das floras do extremo-sul do continente, dos Andes, do sul e centro do Brasil, apresentam numerosas espécies endêmicas (BRADE, 1956). Como em Campos do Jordão (MODENESI, 1988), o mosaico de distribuição da vegetação ajusta-se perfeitamente à compartimentação geomorfológica. Variações da topografia, hidrologia das 


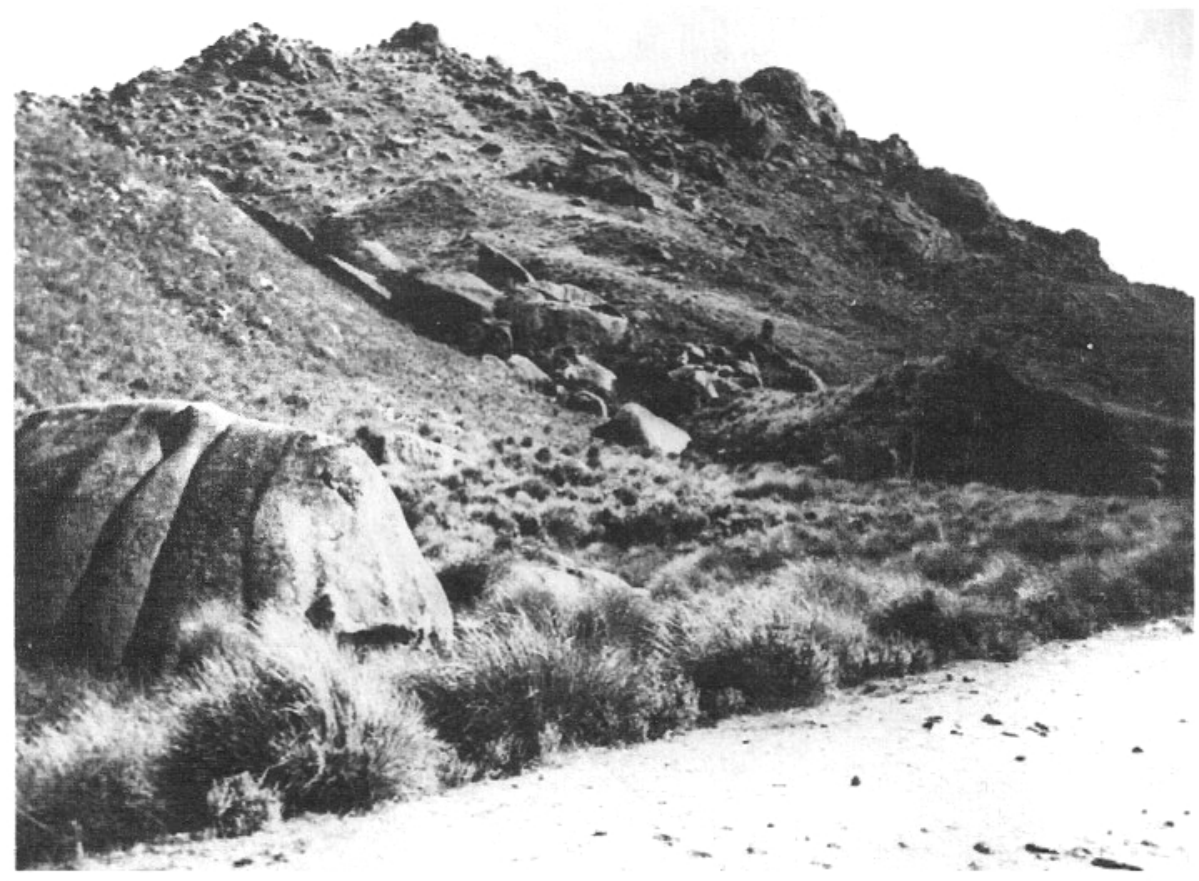

FOTO 2 - Parte frontal de concentração linear de matacões, no divisor Couto-Prateleiras.

vertentes e formações superficiais refletem-se na distribuição e composição dos campos - ora mais ora menos arbustivos - e da vegetação em geral. A continuidade dos campos de altitude é interrompida por alinhamentos de arbustos e pequenas árvores, dispostos ao longo dos rios, e pelos bosques de árvores anãs anichados nas reentrâncias das vertentes, especialmente dos anfiteatros. Turfeiras de tipo herbáceo ocupam o fundo plano e encharcado de pequenas planícies alveolares e cabeceiras de drenagem desenvolvidas a montante de soleiras rochosas (Figuras 1 e 2, Fotos 1, 3 e 5).

Esta análise das formas e depósitos de vertente do planalto do Itatiaia seguiu diretrizes metodológicas empregadas anteriormente em estudos geomorfológicos no planalto de Campos do Jordão (MODENESI, 1980, 1988). Caracterização da estrutura e textura das formações superficiais de vertente, assim como de sua distribuição espacial e relações com as formas, tiveram por fim estabelecer uma cronologia relativa dos materiais e identificar os processos responsáveis pela evolução das encostas. A classificação textural adotada foi a de SHEPARD (1954). Levantamentos de detalhe e coleta de amostras concentraram-se no curso superior do ribeirão das Flores (vale dos Lírios). Observações complementares foram efetuadas na parte central do planalto, em áreas próximas à
Pedra do Altar e nas cabeceiras do ribeirão Aiuruoca.

\section{AS VERTENTES E SEUS DEPÓSITOS}

A análise das formas e depósitos de vertente concentrou-se em três áreas da bacia do ribeirão das Flores: nas planícies alveolares desenvolvidas a montante do Abrigo Rebouças (várzeas do camping e da Geladeira - Fig. 1), na cabeceira de um seu afluente, no início da trilha que desce em direção ao Abrigo Massena, e ao longo da mesma trilha, na vertente norte das Prateleiras (Figura 2), já nas bordas do planalto.

$\mathrm{O}$ ribeirão das Flores corta o planalto em vale retilíneo e relativamente largo (Figura $1 \mathrm{e}$ Foto 1), ajustado a um falhamento W-WNW (PENALVA, 1966; RICCOMINI, 1989). Amplitudes de quase $300 \mathrm{~m}$ separam a planície aluvial (aproximadamente $2.400 \mathrm{~m}$ ) dos divisores da margem esquerda $(2.665 \mathrm{~m})$ e do Morro do Couto $(2.680 \mathrm{~m})$, na margem direita. Ao longo de seu curso superior, planície alveolares - geralmente assimétricas e preenchidas por sedimentos turfosos - alternam-se com soleiras rochosas ou trechos encachoeirados.

O modelado dos altos campos do Itatiaia é essencialmente erosivo e caracterizado por dissecação intensa. No topo dos interflúvios, assim 


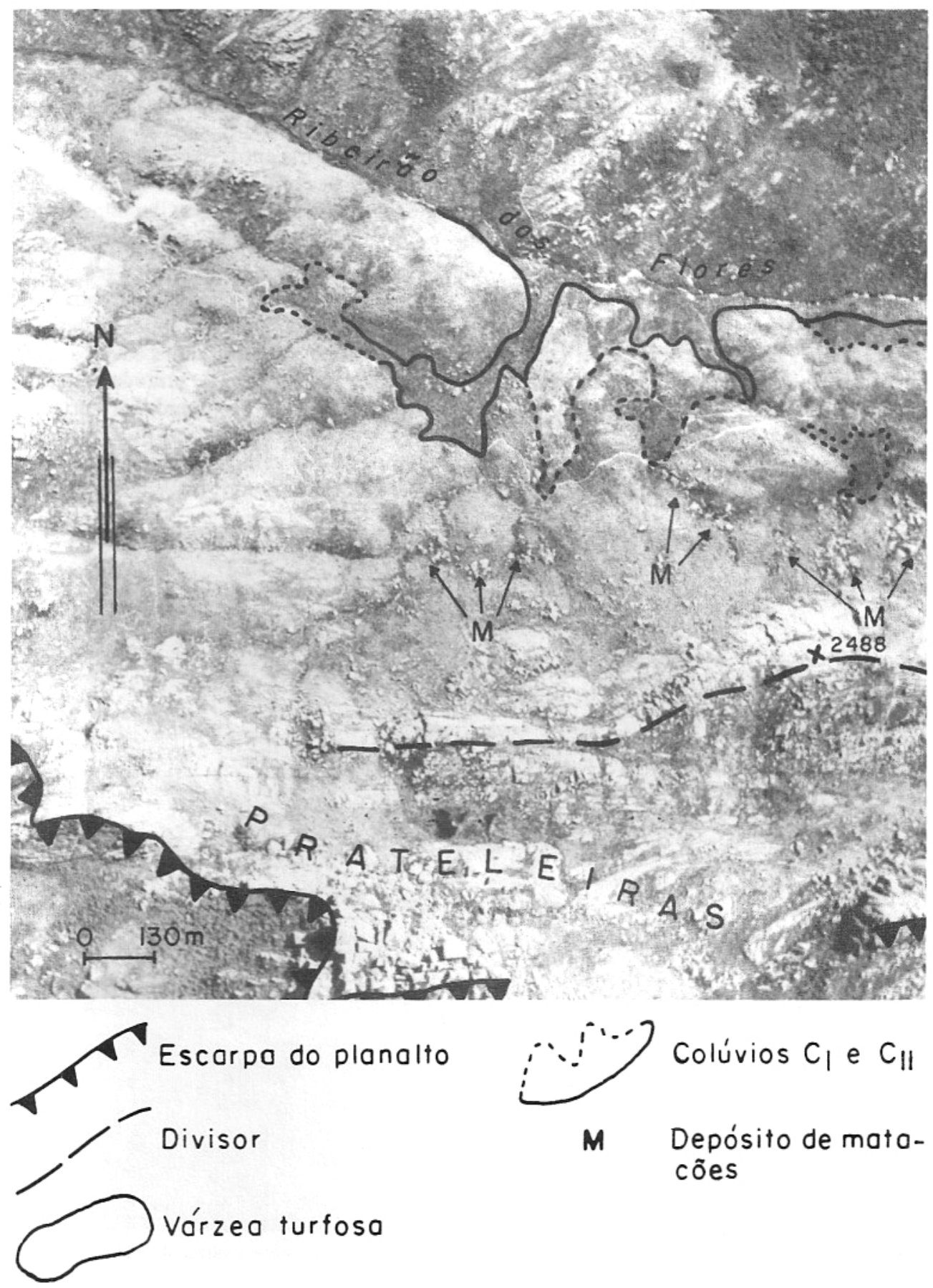

FIGURA 2 - Várzeas e depósitos de vertente situados a jusante do Abrigo Rebouças. Afloramentos em tons claros de cinza, campos de altitude em cinza-médio e vegetação mais densa em cinza-escuro.

como na maior parte das encostas, afloramentos expõem as estruturas (Figuras 1 e 2). Paredões rochosos apresentam um padrão típico de caneluras, desenvolvido sobre os sistemas de juntas das alcalinas. Blocos e matacões (Figura 2, Fotos 2, 3 e 5), in situ (dispostos segundo as direções estruturais) ou transportados (sem orientação nítida), revestem os demais setores das encostas. A forma dos interflúvios parece variar em função da intensidade dos diaclasamentos. Sobre rochas pouco diaclasadas, cristas mais ou menos amplas têm um aspecto maciço, bordas arredondadas e seção convexa (Figuras 1 e 2). Sobre rochas muito diaclasadas - principalmente onde se cruzam sistemas de juntas ortogonais - os topos têm aspecto ruiniforme, com gran- 
des matacões de arestas subarredondadas, dispostos segundo as direções de diaclasamentos e fraturas e separados por fendas profundas e largas (Figura 2). Característica de alguns topos do planalto (Prateleiras), esta topografia ruiniforme também pode ser observada em níveis mais baixos, embutidos, ou nos pequenos morros isolados da várzea do ribeirão das Flores.

Vertentes laterais (áreas com curvas de nível dispostas paralelamente aos cursos d'água) íngremes (Figuras 1 e 2), com perfis retilíneos de declividade superior a $40^{\circ}$, são as formas mais comuns de encostas. Lombas (Figuras 1 e 2, Foto 1) - partes salientes dos interflúvios, onde as curvas de nível apresentam traçado convexo em relação aos cursos d'água - de declividade variada têm seus perfis geralmente ajustados ao mergulho dos sistemas de juntas das alcalinas quartzo- sas do planalto. Os perfis verticais ou íngremes da parte superior das vertentes free faces podem ser substituídos, a partir da vertente média, por setores sucessivamente inclinados, com rampas rochosas (menos de $30^{\circ}$ ) recobertas por blocos e matacões (a maioria entre 20 e $200 \mathrm{~cm}$ ), ou por materiais rasos de recobrimento (Figuras 1 e 2). Depósitos coluviais mais espessos limitam-se a alguns poucos patamares nas vertentes médias.

Nas free faces a cobertura vegetal restringese às reentrâncias dos paredões de rocha nua: caneluras e fendas que separam blocos rochosos. Sobre os solos rasos, desenvolvidos entre os afloramentos, ocorrem campos de altitude (Figuras 1 e 2, Fotos 1, 3 e 4). Comunidades variadas ajustam-se às diferentes condições de drenagem, solos e proteção dos ventos. Arvoretas e arbustos podem ocorrer perto dos matacões (Foto 3 ).

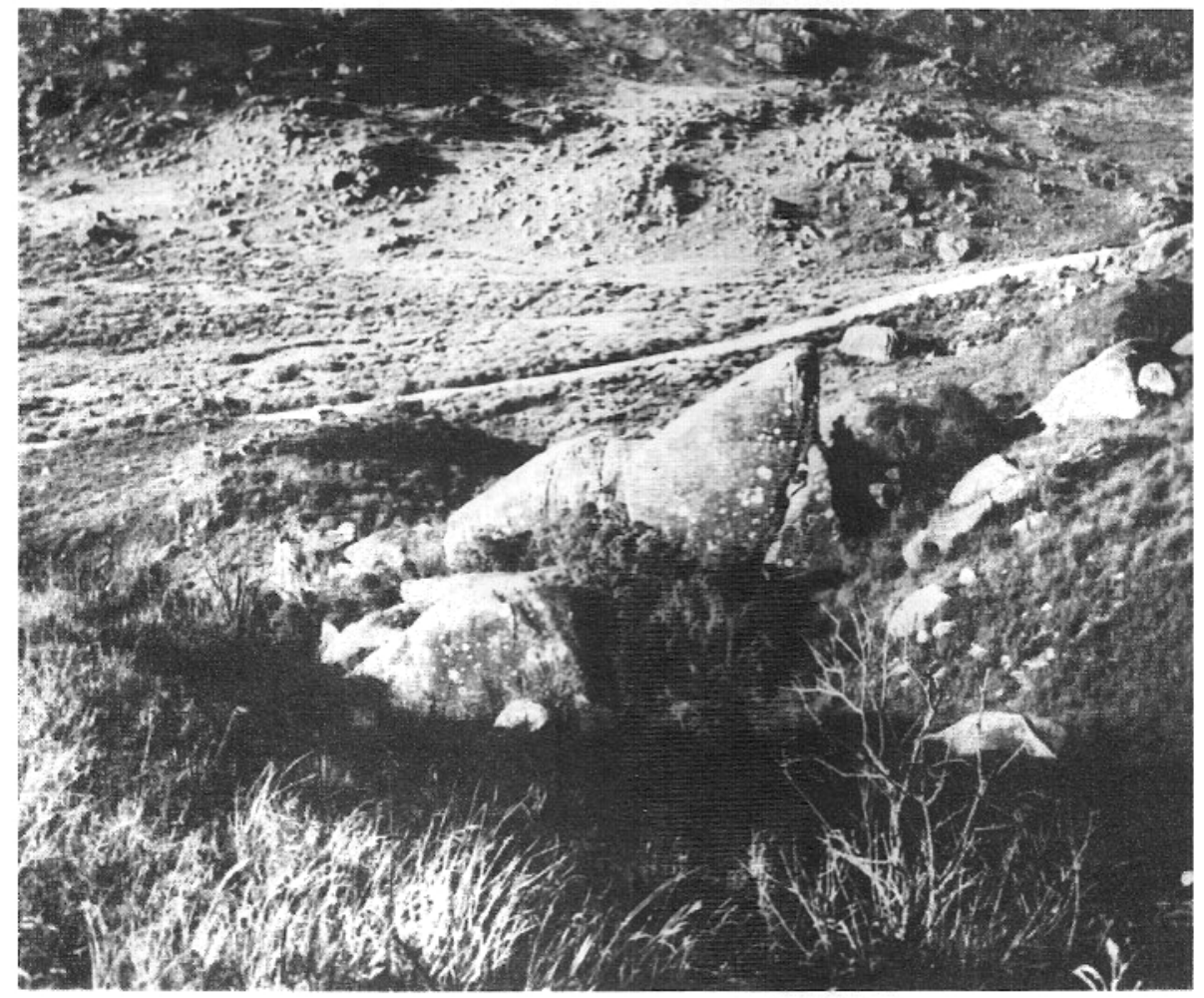

FOTO 3 - Talus cone, com matacões de até $12 \mathrm{~m}$ de eixo maior, suspenso sobre a várzea do ribeirão das Flores. Note-se a vegetação arbustiva.

Anfiteatros rasos e pouco marcados - menos numerosos e sem a concavidade acentuada das escarpas que circunscrevem formas similares do planalto de Campos do Jordão (MODENESI, 1988, 1989) - constituem uma terceira forma de vertente (Figuras 1 e 2). Seu perfil longitudinal é caracterizado por porção superior retilínea e setor inferior côncavo. Nos trechos mais estreitos do vale do ribeirão das Flores, os anfiteatros estão suspensos, separados do talvegue atual por um setor dissecado, de perfil retilíneo.
Onde o vale se abre em alvéolos, a seção basal côncava prolonga-se para jusante por rampas de declividade decrescente, que invadem e reduzem a planície aluvial (Figuras 1 e 2, Foto 5). Sítios preferenciais de concentração de umidade, de maior profundidade do intemperismo e de retenção de depósitos, os anfiteatros rasos suportam uma vegetação densa, com árvores anãs (geralmente com 5 a $6 \mathrm{~m}$ de altura), que contrasta com os campos das demais áreas das vertentes. 
A passagem das vertentes médias para as rampas pouco inclinadas das baixas encostas é marcada, com freqüência, por depósitos muito grossos, constituídos por blocos e matacões de até $12 \mathrm{~m}$ de eixo maior, praticamente desprovidos de materiais finos.

Reconhecidos anteriormente como talus cones suspensos (Foto 3) no nível das fontes (MODENESI, 1989), alguns destes depósitos correspondem, na realidade, à parte frontal de concentrações lineares de blocos e matacões que revestem pequenos vales de primeira ordem (Foto 2). Nos dois casos situam-se abaixo de free faces talhadas em rochas muito fraturadas, nas quais persistem nítidas as cicatrizes da queda de blocos. A movimentação dos matacões é evidenciada pela posição diferente das caneluras, nas paredes rochosas e nos matacões dos depósitos. Concentrações lineares dispõem-se quase sempre segundo direções preferenciais de diaclasamento e fratura. Vegetação arbustiva preenche os espaços entre os matacões.
Num dos depósitos de tálus parece haver superposição de dois tipos de materiais: (1) matacões maiores, subangulosos e menos alterados, muitas vezes com caneluras numa das faces, sobre (2) blocos e matacões menores, geralmente arredondados e com evidências de alteração esferoidal. Os elementos maiores ocorrem sempre na parte superior e frontal dos depósitos.

As rampas pouco inclinadas das baixas encostas (Fotos 4 e 5) são constituídas por duas gerações de colúvios com características diversas. Ao longo do vale do ribeirão da Flores, estes materiais formam dois níveis de rampas - com inclinação, respectivamente, de $14-16^{\circ}$ e e $4-^{\circ}$. separados por degraus. Nos alvéolos menores, as duas gerações de colúvios podem aparecer superpostas, como por exemplo em várzeas suspensas na cabeceira de vales de primeira ordem e em patamares das vertentes, onde a quebra de gradiente favorece a deposição e retenção dos materiais em trânsito.

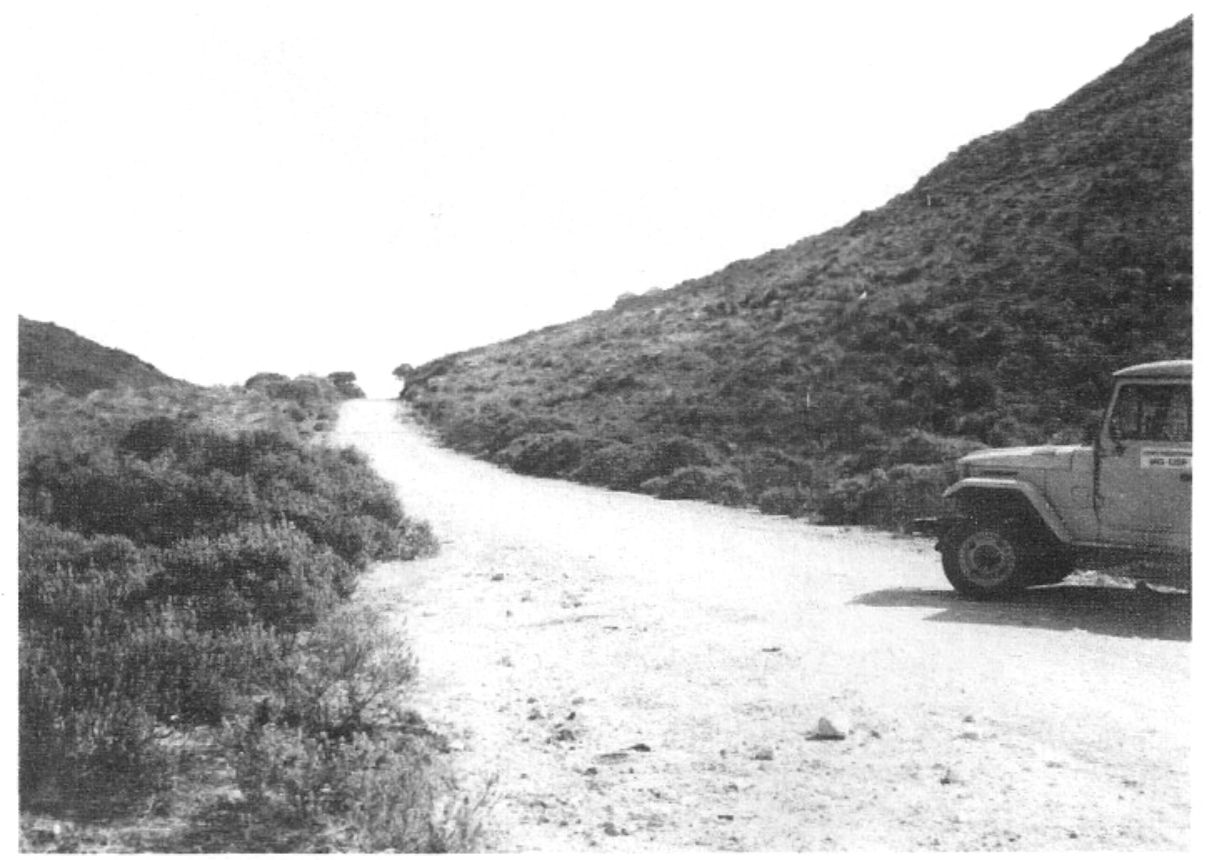

FOTO 4 - Rampa dos colúvios $\mathrm{C}_{\mathrm{I}}$, na cabeceira do ribeirão das Flores.

Recobrimento vegetal diferenciado pode acentuar a transição rampa-várzea: Cortaderia modesta predomina nas várzeas úmidas e auréolas de Chusquea pinifolia marcam o limite com as rampas. As várzeas são colmatadas por seqüências relativamente uniformes de sedimentos turfosos, muito gelificados e fortemente ácidos (pH entre 4,5 e 5), com espessura máxima observada de $260 \mathrm{~cm}$. Apesar da cor preta intensa, os teores de matéria orgânica destes materiais são pouco elevados. Morros rebaixados segmentam as várzeas turfosas onde matacões isolados podem ocorrer (1) in situ, com as mesmas direções de juntas expostas nas vertentes, ou (2) transportados, neste caso concentrandose, principalmente, em frente às rampas rochosas das lombas.

Os colúvios mais antigos $\left(\mathrm{C}_{\mathrm{I}}\right)$ repousam sobre a rocha alterada (Foto 6); com espessura geralmente inferior a $1 \mathrm{~m}$, são desprovidos de 
estruturas, maciços e compactos, conglomeráticos e extremamente heterométricos. Apresentam grande quantidade de seixos (em média, $25 \%$ do total da amostra), blocos e matacões (com até $50 \mathrm{~cm}$ de eixo maior, freqüentemente com córtex de alteração) dispersos em matriz argilosa amarelada ou amarelo-brunada, com manchas esbranquiçadas e vermelho-amareladas devidas à presença de feldspato alterado e de nódulos ferruginosos. Esta matriz possui teores elevados de argila (48 a 50\%), conteúdos semelhantes de silte (22 a $25 \%$ ) e areia (25 a $30 \%$ ) e grânulos (2 a $5 \%$ ), principalmente de feldspato alterado. Os parâmetros estatísticos definem materiais muito pobremente selecionados, com diâmetro médio na fração silte fino-silte médio, assimetrias muito negativas e valores de curtose dentro do limite das curvas platicúrticas.

As seqüências coluviais da última geração $\left(\mathrm{C}_{\mathrm{II}}\right.$, Foto 7$)$ formam o nível mais baixo de rampas e se estendem sobre os depósitos turfosos das várzeas (Foto 5). Sua espessura é maior (até $240 \mathrm{~cm}$ ) nas pequenas várzeas das cabeceiras, onde recobrem colúvios $\mathrm{C}_{\mathrm{I}}$. São característicos o seu aspecto cascalhento e o forte contraste de cor entre a matriz escura (preta a bruno-acinzentada muito escura) e os numerosos grânulos e pequenos seixos esbranquiçados (feldspato pouco alterado), amarelados (feldspato alterado) e avermelhados (nódulos ferruginosos). A matriz destes colúvios possui teores variados de argila (32 a 60\%), silte ( 28 a $34 \%$ ) e areia (19 a $49 \%$ ), que se distribuem no perfil sem qualquer tendência nítida. Os valores do diâmetro médio (silte fino - silte grosso) e desvio padrão (muito pobremente selecionados) são semelhantes aos dos $C_{I}$ e os de assimetria (simétricos a muito negativos) e curtose (platicúrticas e muito platicúrticas) mais variados.

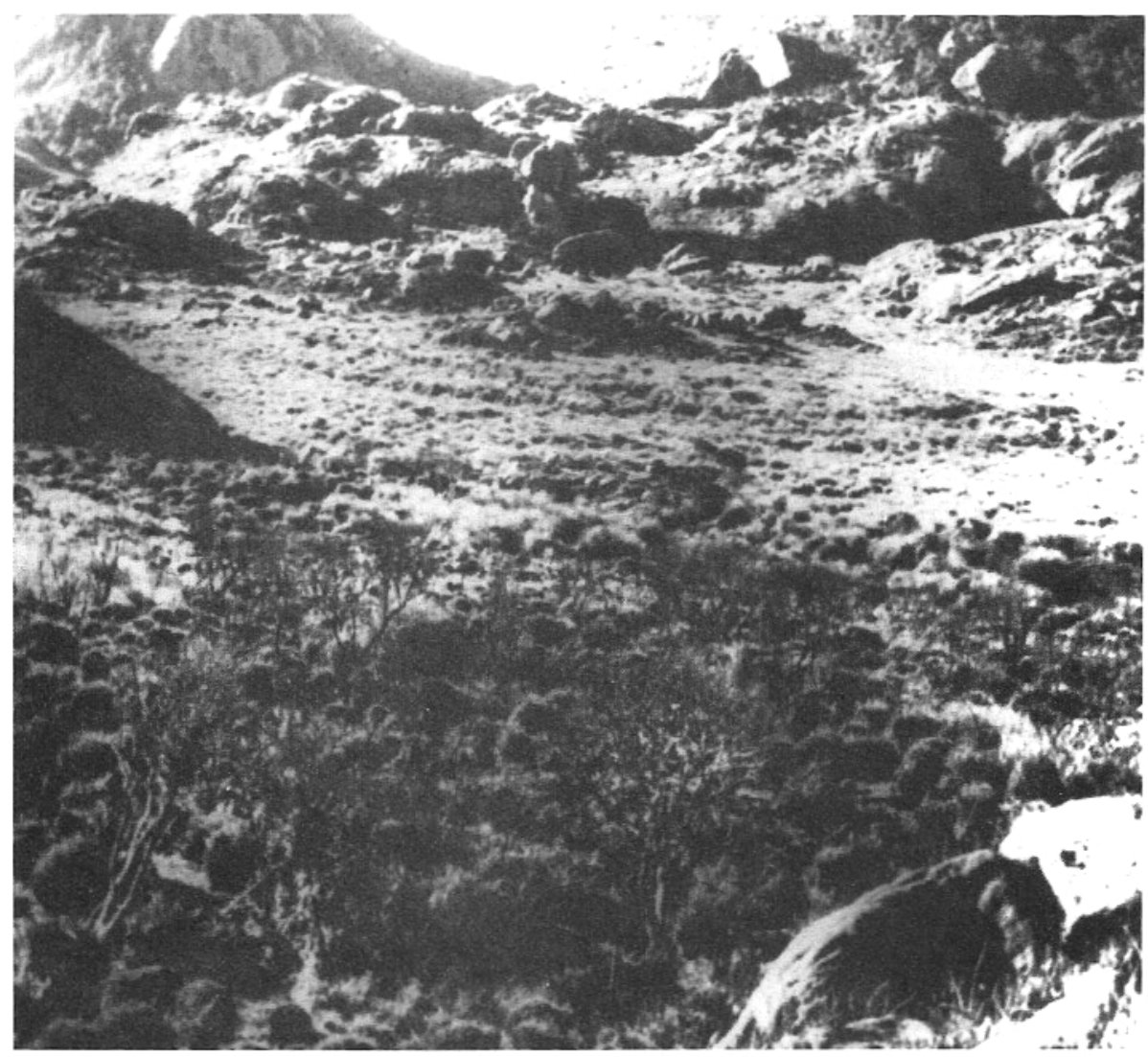

FOTO 5 - Touceiras queimadas de Cortaderia modesta marcam a rampa dos colúvios $\mathrm{C}_{\mathrm{II}}$ que se estende sobre a várzea do camping.

Menos heterométricos, os $\mathrm{C}_{\mathrm{II}}$ contêm clastos angulares e subangulares, geralmente inferiores a 2 ou $3 \mathrm{~cm}$ (excepcionalmente $5 \mathrm{~cm}$ ), concentrados em determinados níveis do perfil. A quantidade de seixos esparsos na matriz (até $8 \%$ do to-

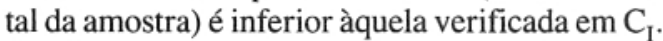
Os blocos e matacões contidos no interior destes colúvios, ou a ele sobrepostos, ocorrem quase sempre menos alterados. Variações de cor e textura, comuns principalmente nos perfis mais espessos, evidenciam a superposição de camadas de materiais diferentes, mais que subdivisões de um mesmo horizonte humífero. A falta de boas exposições não permitiu confirmar, mas em alguns 
locais - por exemplo na margem direita do ribeirão das Flores, aproximadamente $800 \mathrm{~m}$ a montante do Abrigo Rebouças - os $\mathrm{C}_{\mathrm{II}}$ se interdigitam com os sedimentos de várzea. As duas seqüências, situadas em posições topográficas diferentes, parecem correlacionar-se: as camadas cascalhentas dos perfis de vertente corresponderiam às concentrações ou lentes de areia grossa, grânulos e pequenos seixos encontradas nos depósitos turfosos das várzeas (MODENESI \& MELHEM, 1986). Estes têm a parte inferior (260 a $210 \mathrm{~cm}$ ) constituída por sedimentos argilosílticos, com $7 \%$ de matéria orgânica, e a porção central (210 a 70cm) argilosa (76 a 83\% de argila), com 20 a $23 \%$ de matéria orgânica. Nos $70 \mathrm{~cm}$ superiores das seqüências de várzeas a textura passa de argilo-síltica a arenosa e os teores de matéria orgânica caem de $9 \%$ para apenas $0,1 \%$. Ph entre 4,5 e 5,5 , teores de matéria orgânica baixos para definir turfas verdadeiras e quantidades variáveis de restos vegetais não decompostos são características próprias das turfas tropicais de altitude encontradas no Itatiaia e em Campos do Jordão (MODENESI, 1988).

Na borda noroeste do planalto, nas cabeceiras do córrego do Brejo da Lapa (num barranco da estrada do Abrigo Rebouças, 250m após o Ho- tel Alséne), um depósito de vertente com características especiais encontra-se sotoposto aos colúvios $\mathrm{C}_{\mathrm{I}}$ e $\mathrm{C}_{\mathrm{II}}$, separado por linha de blocos e lajes com 30 a $40 \mathrm{~cm}$ e, excepcionalmente, até $130 \mathrm{~cm}$ de eixo maior. Constituído por seixos com eixo maior inferior a $2 \mathrm{~cm}$ e blocos de 12 a $20 \mathrm{~cm}$ achatados e angulosos, de rocha muito alterada (brechas magmáticas), diferencia-se dos demais colúvios por apresentar os clastos soltos, praticamente sem matriz (Foto 8) - apenas farinha de rocha resultante da desagregação e alteração dos seixos e blocos -, acamamento plano-paralelo e cor mais clara, bruno-amarelada clara. Apesar de os clastos contidos no depósito serem semelhantes aos fragmentos de rocha dos perfis de alteração in situ, nestes últimos os fragmentos se dispõem irregularmente, sem orientação.

Ao contrário do que ocorre em Campos do Jordão - onde dois níveis de linhas de pedra são comuns nas formações superficiais do topo dos morros, lombas e vertentes laterais (MODENESI, 1988) - , no Itatiaia observa-se uma única linha de pedras, geralmente descontínua e tênue, na base do horizonte $\mathrm{A}$ dos solos de algumas vertentes médias, entre os colúvios $\mathrm{C}_{\mathrm{I}}$ e $\mathrm{C}_{\mathrm{II}}$ ou, mais raramente, entre o horizonte superficial e a rocha alterada in situ.

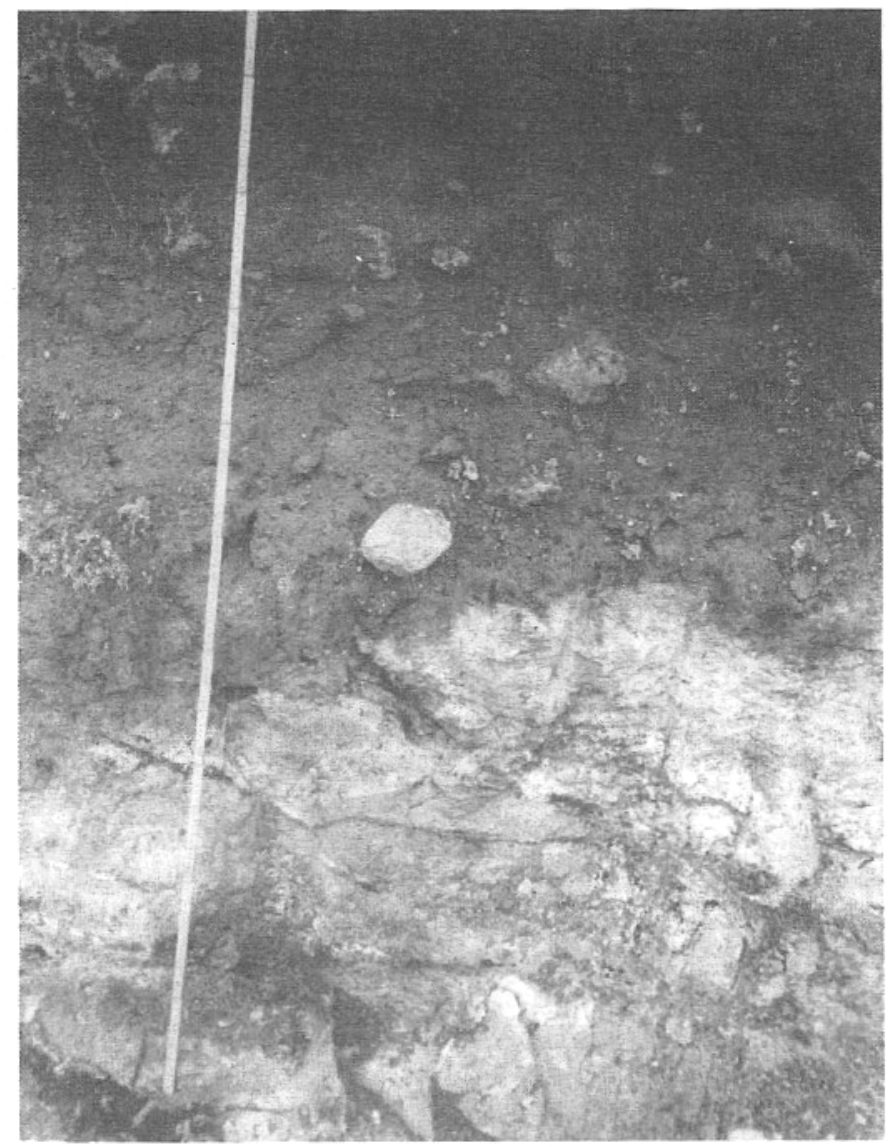

FOTO 6 - Colúvios $C_{1}$ de espessura inferior a $1 \mathrm{~m}$; blocos de rocha em diferentes graus de alteração, dispersos em matriz argilosa amarelada ou amarelo-brunada. 


\section{A EVOLUÇÃO DAS VERTENTES}

A originalidade da paisagem do Itatiaia não se deve apenas a fatores litológicos e estruturais mas também às influências climáticas e morfodinâmicas do acentuado ressalto do planalto. Suas formações superficiais exibem distribuição espacial semelhante à observada na vizinha cimeira dos Campos do Jordão (MODENESI, 1980, 1984, 1988 e 1988a): depósitos mais espessos formam rampas ou patamares nos baixos e médios setores das vertentes em anfiteatro (Fi- guras 1 e 2). No restante dos interflúvios o afloramento generalizado das alcalinas expõe as estruturas e condiciona o relevo. Depósitos de seixos angulosos, tálus e concentrações lineares de blocos e matacões e duas gerações de colúvios testemunham fases de intensificação das atividades erosivas e deposicionais nas vertentes. As características dos materiais sugerem a atuação de diferentes processos na evolução das vertentes, processos estes relacionados à provável variação das condições climáticas durante o Quaternário.

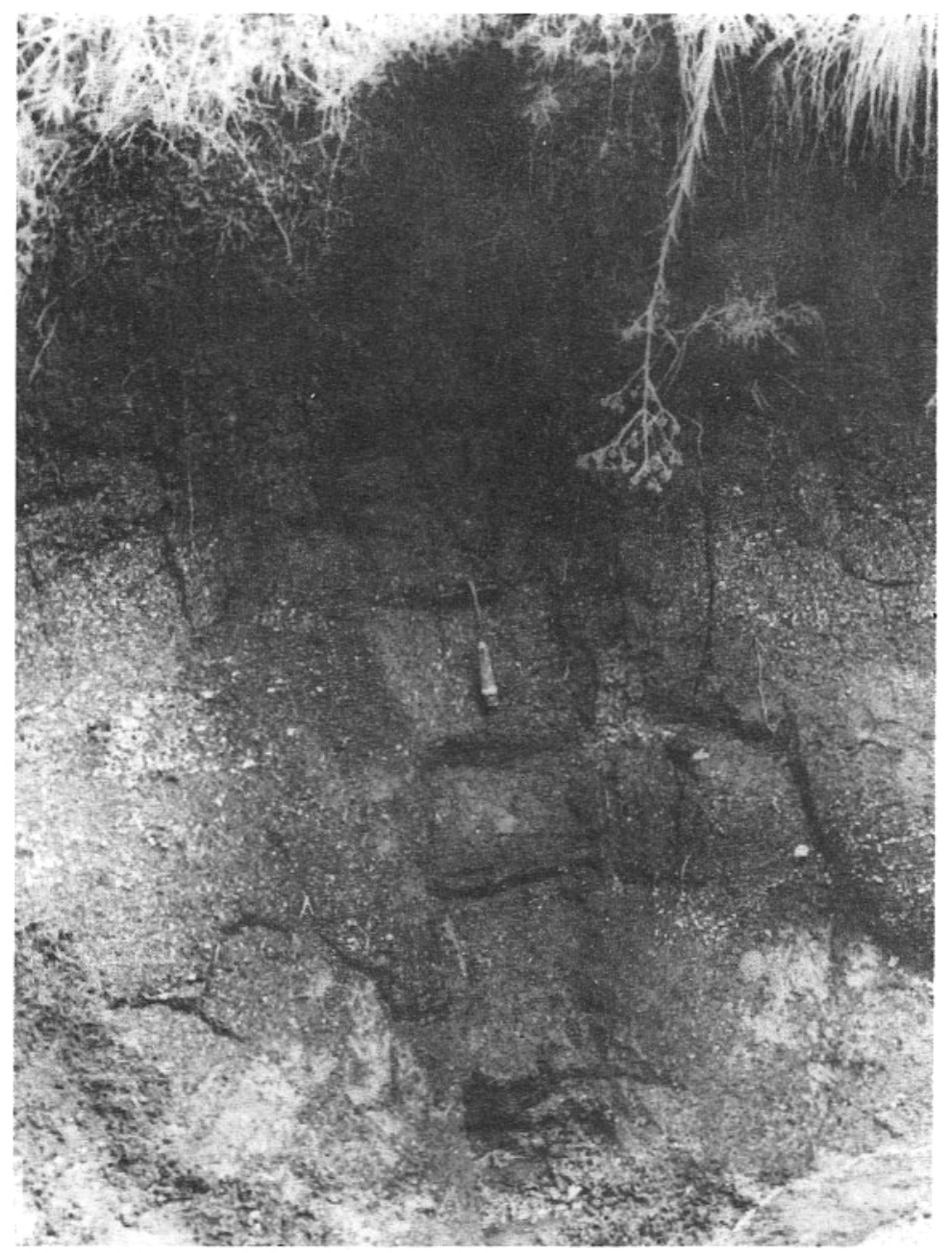

FOTO 7 - Colúvios $C_{\text {III }}$, com espessura de $2,50 \mathrm{~m}$ e forte contraste de cor entre a matriz escura e os grânulos e pequenos seixos concentrados em diferentes níveis do perfil.

Talus cones e concentrações lineares de blocos e matacões estão fossilizados pela vegetação e suspensos nas vertentes ou em vales de primeira ordem; intensidade e direções do sistema de juntas das alcalinas condicionam a produção de detritos e a disposição dos sedimentos. Estes depósitos de textura muito grossa refletiriam a ação pretérita de processos de clima frio e úmido, com ciclos de congelamento e degelo mais numerosos, e tal- vez mais longos, capazes de explicar o tamanho e abundância dos clastos. Os blocos menores, mais arredondados e alterados da parte inferior dos depósitos de tálus seriam o resíduo de antigos movimentos de massa - desencadeados em condições úmidas frias (solifluxão) ou mesmo mais quentes (corridas de lama) - posteriormente expostos à ação do escoamento superficial. O depósito de seixos angulosos da borda do planalto foi interpretado 


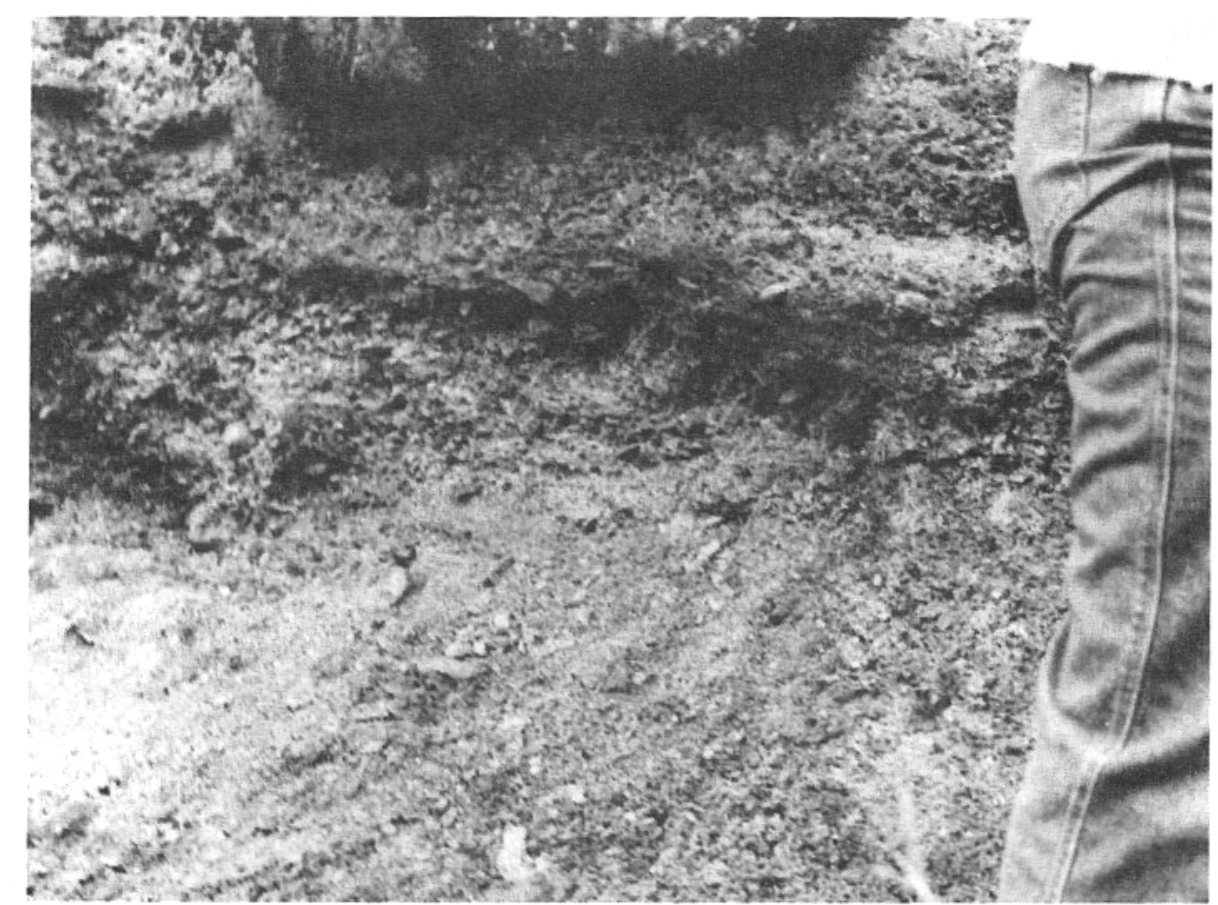

FOTO 8 - Depósito de seixos e blocos, achatados e angulosos, sem matriz, sotoposto aos dois níveis de colúvios.

como um antigo scree ou tálus de montanha de clima frio - depósitos formados principalmente pela contribuição de processos de fragmentação por congelamento e degelo - enterrado pelos materiais das duas fases de coluviação.

Um resfriamento da ordem de 4 a $6^{\circ} \mathrm{C}-$ admitido para esta área da América do Sul (CLIMAP, 1976 e GATES, 1976) - durante o último máximo glacial (18.000 anos BP) permitiria considerar temperaturas médias anuais de 7 ou $5^{\circ} \mathrm{C}$ para o Itatiaia, semelhantes às observadas atualmente na Escandinávia, Canadá ou Alasca. Insuficientes para caracterizar ambientes glaciais ou periglaciais com permafrost, tais temperaturas e a presença de umidade teriam sido responsáveis pela multiplicação dos ciclos diários de congelamento e degelo, considerados por vários autores (TRICART, 1956; POTTS, 1970 e BIROT, 1981, entre outros) como a principal causa da gelivação. A ação direta dos cristais de gelo, mais eficiente em superfície (CHAMBERS, 1966; FRENCH, 1976), seria completada pelo efeito indireto do congelamento da água nos poros e fissuras das rochas - hidrofracturing (SELBY, 1982) - , importante em profundidade e capaz de separar grandes massas rochosas (DUNN \& HUDEC, 1966 e HRADEK in SELBY, 1982).

A estes processos, especialmente ativos em rochas muito fissuradas, somar-se-iam os efeitos do alívio de tensões internas das rochas importante principalmente na produção de de- tritos muito grossos (SELBY, 1982) - e de pressões hidrostáticas exercidas nas juntas pelas águas de percolação (CLARK \& SMALL, 1982). Fenômenos de alteração são importantes na produção de detritos e na instabilização das vertentes do planalto. Condições de umidade, decorrentes da posição de cimeira exposta à penetração dos ventos úmidos de sul e sudeste, favoreceram e continuam a favorecer o intemperismo químico, como já observaram ODMAN (1952), DRESCH (1957), MACAR (1957) e RAYNAL (1957), entre outros. Média anual de $11,5^{\circ} \mathrm{C}$ e pluviosidade superior a $2.000 \mathrm{~mm} /$ ano colocam o planalto na zona de intensidade máxima do intemperismo químico (PELTIER, 1950). A esfoliação é comum nos blocos e matacões expostos ou contidos nos depósitos.

Além de refletir a influência dos fatores clima e intemperismo, as fases mais agressivas de recuo das encostas do planalto do Itatiaia devem ter explicações tectônicas. Evidências morfológicas de duas retomadas do soerguimento do planalto de Campos do Jordão no Pleistoceno Superior (MODENESI, 1984, 1988, 1988a) e de falhamentos de idade pleistocênica superior e, provavelmente, holocênica nas Bacias de Resende e Taubaté (RICCOMINI et al., 1989) sugerem a interferência de sismicidade na liberação dos enormes blocos e matacões encontrados nos depósitos de tálus. Deve-se lembrar que (1) o planalto do Itatiaia faz parte da Zona Sismogênica de Cunha (HASUI et al., 1982) e (2) o efeito 
cumulativo a longo prazo de vários sismos de baixa magnitude pode ser importante na desestabilização das vertentes (SELBY, 1982).

Concluindo, a deposição de materiais de textura muito grossa nas vertentes do planalto refletiria um conjunto de fatores e processos, alguns mais importantes no passado. Blocos e matacões das vertentes do vale do ribeirão das Flores e screes da borda do planalto - assim como os depósitos de seixos angulosos, do sopé das Agulhas Negras, descritos por RAYNAL (1957), analisados por HAMMELIN \& CAILLEUX (1957) e por eles interpretados como de origem periglacial - referem-se a um conjunto de ações de amplo espectro, que deveria incluir processos de gelivação (frost action), ativos em fases frias do Pleistoceno Superior.

A idéia de ações glaciais e periglaciais no Itatiaia - levantada por DE MARTONNE (1940) e aceita por muitos autores (SILVEIRA, 1942; RUELLAN, 1943; VALVERDE, 1952; RICH, 1953; RAYNAL, 1957 e 1957a; BROCHU, 1957; MACAR, 1957; LEFÉVRE, 1957; HAMMELIN \& CAILLEUX, 1957; AB'SÁBER \& BERNARDES, 1958; LEHMAN, 1960; EBERT, 1960 e BARBOSA 1962), mas contestada por DOMINGUES (1952), ODMAN (1952), BIROT (1957), DRESCH (1957), MORTENSEN (1957), TEIXEIRA (1961) e PENALVA (1967) - não pode ser totalmente afastada, mas deveria ser entendida apenas em termos da ação de gelivação e de processos associados, ação esta nem sempre restrita às regiões periglaciais (FRENCH, 1985).

Segundo CAILLEUX (1957) e LEFÈVRE (1957) a posição geográfica excepcional do Itatiaia teria favorecido a ocorrência de fortes quedas de neve nas épocas glaciais. No presente, a análise dos dados meteorológicos permite caracterizar uma estação seca de apenas três meses, enquanto geadas e temperaturas abaixo de zero são freqüentes em períodos maiores - respectivamente, de 8 ou 9 meses e de 5 a 7 meses o que levaria a admitir a possibilidade de nevadas abundantes no último período glacial, mesmo sem necessidade de inversão, sugerida por PENALVA (1967), no regime das precipitações.

EBERT (1960) admite a ocorrência de um pequeno ciclo glacial mais antigo - Riss - no topo do planalto, baseado no estudo dos sedimentos do vale do rio Preto e de seu afluente Bonito. Tais sedimentos correlacionar-se-iam à formação de vales em U e circos glaciais suspensos e retrabalhados por esvaziamentos sucessivos (AB'SÁBER \& BERNARDES, 1958). Velhos circos glaciais, vales em U, morainas e outras evidências de uma glaciação de montanha, apontadas pelos autores acima citados (principal- mente RICH, 1953; RAYNAL, 1957; AB'SÁBER \& BERNARDES, 1958 e EBERT, 1960), não resistem a uma análise mais detida das formas e depósitos do planalto.

Por exemplo, blocos e matacões distribuemse por todos os setores dos interflúvios - como também observou PENALVA (1967) - e, quando nas planícies aluviais, parecem relacionar-se a transporte sobre as lombas rochosas. Anomalias da drenagem do curso superior do rio Preto - semelhantes às encontradas nos campos de São Francisco (MODENESI, 1988) - testemunhariam a interferência de tectonismo recente, mais que os efeitos de uma " glaciação moderada e localizada" (AB'SÁBER \& BERNARDES, 1958). Da mesma forma, vales em U entalhados por outros mais recentes em V, identificados pelos mesmos autores como vales glaciais dissecados, teriam sua origem no levantamento intermitente do planalto, em analogia com as observações de PO-SHENG (1968) nos flancos da região montanhosa de Chin-ling - China: vales largos, desenvolvidos em períodos de menor levantamento ou de estabilidade do planalto, seriam dissecados por ocasião de levantamentos subseqüentes.

As duas rampas detríticas que se estendem da base dos tálus até as várzeas, com diminuição das declividades e da granulometria dos materiais, podem ser interpretadas como leques aluviais, produto de retrabalhamentos sucessivos dos antigos tálus. Colúvios $\mathrm{C}_{\mathrm{I}}-$ blocos de rocha em diferentes graus de alteração, embalados em matriz amarelada argilosa - teriam sua origem em corridas de lama ou terra, provocadas pela saturação do material intemperizado dos tálus, em épocas de maior intensidade ou concentração das chuvas. Relacionar-se-iam portanto a climas úmidos e provavelmente menos frios, capazes de intemperizar os materiais de vertente - argilificação embrionária descontínua - e de fornecer a água necessária ao desencadeamento das corridas. Colúvios $\mathrm{C}_{\mathrm{II}}$ diferenciam-se dos $\mathrm{C}_{\mathrm{I}}$, principalmente pela redução do número e tamanho dos clastos. Os níveis de concentração de grânulos e pequenos seixos de feldspato pouco alterado, que interrompem os espessos horizontes escuros, representam descontinuidades criadas (1) pela deposição de materiais ora mais finos ora mais cascalhentos ou (2) pela ação seletiva pós-deposicional de processos de escoamento superficial sobre colúvios heterométricos. Nos dois casos haveria perturbação da pedogênese, com superposição de horizontes A. Fases de gelifração intensa podem ter sido responsáveis pelo aumento dos materiais cascalhentos. Os processos de coluviação envolvidos na mobilização e deposição dos $\mathrm{C}_{\mathrm{II}}$ seriam superficiais, remobili- 
zando massas de materiais intemperizados sem destruir os perfis das formações superficiais ou solos subjacentes. A exemplo dos colúvios das lombas do planalto de Campos do Jordão, os $\mathrm{C}_{\mathrm{II}}$ poderiam ser atribuídos à atuação de corridas de lama ou a processos mais lentos, de tipo solifluxão (MODENESI, 1988).

Colúvios $\mathrm{C}_{\mathrm{I}}$ e $\mathrm{C}_{\mathrm{II}}$ parecem corresponder aos dois níveis superiores dos materiais de vertente descritos por RAYNAL (1957) nas vizinhanças das Agulhas Negras, entre 2.100 e $2.500 \mathrm{~m}$, que marcariam a passagem progressiva das condições periglaciais para condições climáticas cada vez mais semelhantes às atuais.

A história geomorfológica do Itatiaia é longa e complexa. A partir da intrusão circular, no Cretáceo Superior, influências do soerguimento do bloco e de outros processos geomorfológicos fizeram-se sentir por todo Terciário e Pleistoceno. Variações climáticas holocênicas, dificilmente detectadas nas posições intermontanas, aparecem bem marcadas nos depósitos de vertente do planalto do Itatiaia, a exemplo do que ocorre nas cimeiras de Campos do Jordão (MODENESI, 1988).

Materiais de vertente de textura muito grossa - tálus de blocos e matacões e depósitos de seixos e blocos achatados e angulosos - refletiriam a interferência de tectonismo recente e a ação de processos particularmente eficientes sob clima frio e úmido, provavelmente durante o máximo glacial do Pleistoceno Superior, entre 16.000 e 14.000 anos BP (KOWSMANN \& COSTA, 1979). Blocos e matacões menores da base dos tálus corresponderiam a eventos erosivos e deposicionais mais antigos, relacionados a flutuações menores dentro da mesma fase (processos de solifluxão) ou a condições anteriores de maior aquecimento e umidade (corridas de lama). O topo das seqüências coluviais de última geração $-\mathrm{C}_{\Pi \mathrm{II}}-$ sobrepõe-se aos sedimentos da várzea do ribeirão das Flores, depositados entre $8.200+280-270$ e $1.090 \pm 210$ anos BP (datações $\mathrm{C}^{14}$, Laboratório de BONDY-ORSTOM, $\mathrm{n}$. 166 e no 178 , respectivamente), mas a provável interdigitação das duas seqüências permite interpretar os colúvios $C_{\mathrm{II}}$ como holocênicos e sincrônicos do preenchimento das planícies aluviais. Os colúvios $C_{\mathrm{I}}$ teriam sido depositados em climas úmidos do Pleistoceno Terminal, caracterizados por provável atenuação do frio, em seguida ao máximo glacial.

As linhas de pedra encontradas algumas vezes na base do horizonte A dos solos das vertentes médias seriam contemporâneas da fase fria e eventualmente mais seca (AB'SÁBER, 1989), que se seguiu à deposição dos colúvios $C_{1}$, no Pleistoceno Terminal.

Os processos de liberação de blocos e matacões, ativos nas vertentes do planalto do Itaiaia durante o Pleistoceno Superior, foram substituídos, a partir do Pleistoceno Terminal e no Holoceno, por processos de menor intensidade erosiva - corridas de terra ou lama e erosão laminar - capazes de retrabalhar apenas os materiais produzidos nas fases erosivas anteriores. Diminuição da atividade morfodinâmica e mudança dos processos atuantes nas vertentes parecem repetir tendências observadas anteriormente na vizinha cimeira de Campos do Jordão (MODENESI, 1988) e em todo o sul e sudeste do Brasil (BIGARELLA \& AB'SÁBER, 1964 e BIGARELLA et al., 1965).

No Planalto do Itatiaia, a sucessão de condições climáticas e ecológicas durante o Quaternário deve ter sido diferente da observada na região andina e nas terras baixas da América do Sul. Esta originalidade resultaria da sua posição de cimeira situada na borda oriental do continente e sujeita ao impacto das massas de ar equatoriais, tropicais e polares. A conclusão das pesquisas abrangentes - incluindo análise das formações superficiais de vertente, relações intemperismomorfogênese e palinologia de sedimentos turfosos de várzeas e depressões hidromórficas - iniciadas em Campos do Jordão e ora em andamento no Itatiaia deverá contribuir para esclarecer a evolução paleoclimática e paleoecológica das montanhas tropicais brasileiras. 


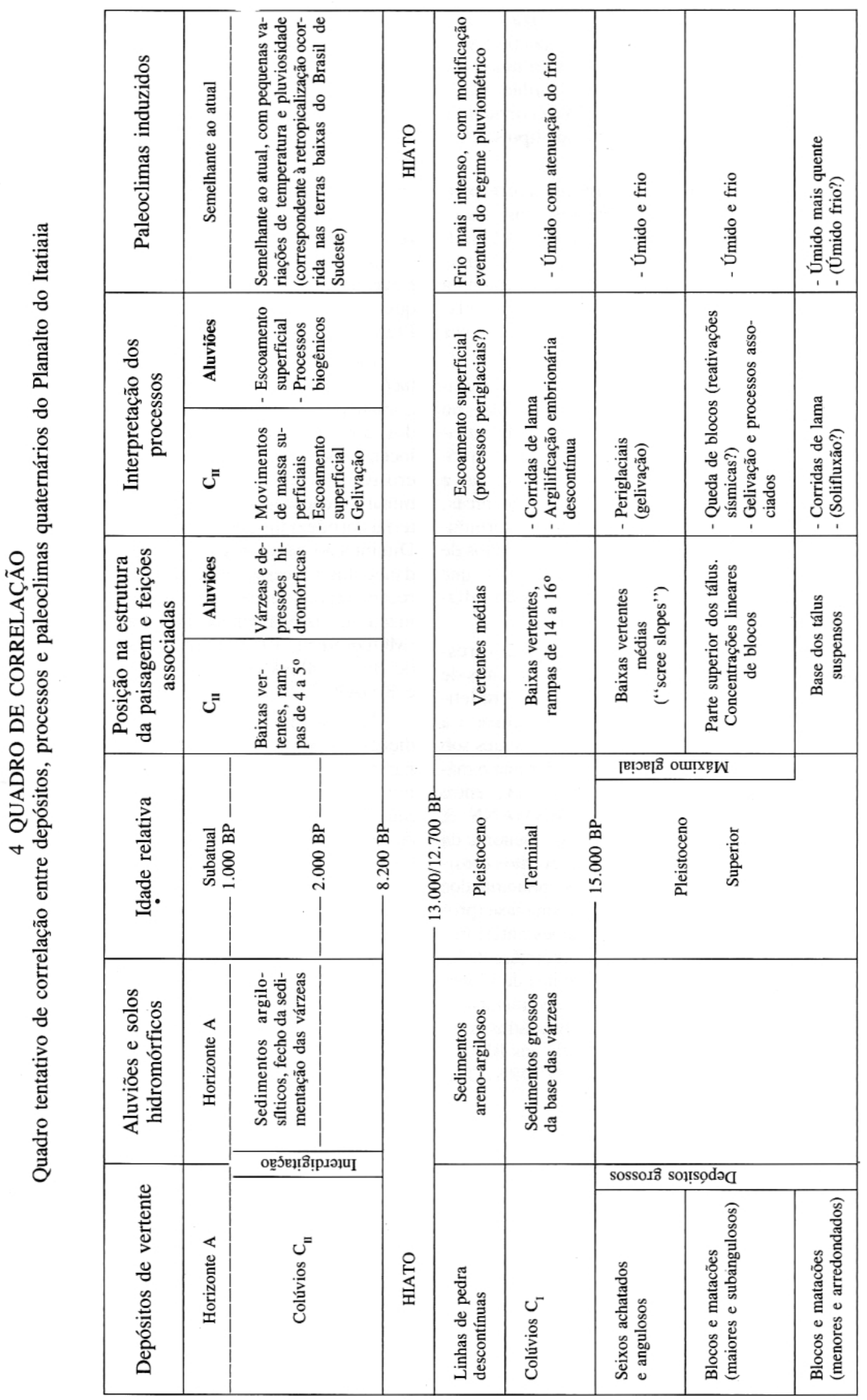




\section{AGRADECIMENTOS}

Ao Professor Aziz N. Ab'Sáber pelas críticas e sugestões. À Fundação de Amparo à Pesquisa do Estado de São Paulo - FAPESP - pelo auxílio financeiro. A autora é bolsista de pesquisa do Conselho Nacional de Desenvolvimento Científico e Tecnológico - CNPq.

\section{REFERÊNCIAS BIBLIOGRÁFICAS}

AB'SÁBER, A.N. 1966. O domínio morfoclimático dos mares de morro no Brasil. IGEOG-USP Geomorfologia. (2), 9p. 1980. Razões da retomada parcial de semi-aridez holocênica, por ocasião do "optimum climaticum". IBILCE-UNESP, Interfácies (8), 13p.

1989. Introdução. In: "Campos de Altitude", Gustavo Martinelli, Editora Índex, p. 16-29.

\& BERNARDES, N. 1958. Vale do Paraíba, Serra da Mantiqueira e arredores de São Paulo. 18 ${ }^{\circ}$ Congresso Internacional de Geografia - Rio de Janeiro, Guia de Excursão (4) 303 p.

AMARAL, G; BUSHE, J; CORDANI, U.G.; KAWASHITA, K; REYNOLDS, J.H. 1967. Potassium-argon ages of alkaline rocks from Southern Brazil. Geoch. Cosmoch. Acta, 31:117-142.

BARBOSA, O 1962. Considerações sobre alguns aspectos geomorfológicos do Itatiaia. Not. Geomorf. (9/10): 66-69.

BIGARELLA, J.J. \& AB'SÁBER, A.N. 1964. Palaegeographische und Palaoklimatische Aspekte des Kanozoikums in Sudbrasilien. Zeitsch. Geomorph. 8(3):286-312.

BIGARELLA, J.J.; MOUSINHO, M.R.; SILVA, J.X. 1965. Processes and Environments of the Brazilian Quaternary. Prepared for the VII INQUA Congress-Fairbanks, Alaska. Impr. Universidade do Paraná, 69 p., Curitiba.

BIROT, P. 1957. Observations a l'Itatiaia. Zeitsch. Geomorph. 1(3):291-292.

1981. Les processus d'érosion a la surface des continents. Masson et Cie. Eds, 605 p., Paris.

BROCHU, M. 1957. Ocurrence possible de glaciations locales pléistocènes et de phénomènes periglaciaires au Brésil. Zeitsch. Geomorph. 1(3): 271-276.

CHAMBERS, M. J. 1966. Investigations of patterned ground at Signy Island, Smith Orkney Island. British Antartic Survey. Bulletin, 9:21-40.

CLARK, M. \& SMALL, J. 1982. Slopes and Weathering, Cambridge Univ. Press, 112 p., Cambridge.
CLIMAP PROJECT MEMBERS 1976. The Surface of the Ice-Age Earth. Science, 191(4232):1131-1137.

DE MARTONNE, E. 1940. Problémes Morphologiques du Brésil Tropical Atlantique. Annales Géographie 49(277):1-27 e (278/9): 106-129.

DOMINGUES, A.J.P. 1952. O maciço do Itatiaia. Rev. Bras. Geog. 14(4):463-471.

DRESCH, J. 1957. Remarques géomorphologiques sur l'Itatiaia. Zeitsch. Geomorph. 1(3):289-291.

DUNN, J.R. \& HUDEC, P.P. 1966. Water, clay and rock soundness. Ohio Journal of Science, 66:153-167.

EBERT, H. 1960. Novas observações sobre a glaciação pleistocênica na serra do Itatiaia. Anais, Academia Brasileira de Ciências, 32(1):51-73.

FRENCH, H.M. 1976. The Periglacial Environment. Longman, London.

1985. Periglacial. In "The Encyclopaedic Dictionary of Physical Geography", A. Goudie et al. Eds, Blackwell, Oxford. GATES, W. L. 1976. Modeling the Ice-Age Earth. Science 191(4232):1138-1144.

HAMMELIN, L.E. \& CAILLEUX, A. 1957. Sables, Cailloux et Canelures de l'Itatiaia. Zeitsch. Geomorph. 1(3):308-312.

HASUI, Y.; ALMEIDA, F.F.M.; M. MIOTO, J. A. e MELO, M. S. 1982. Geologia, tectônica, geomorfologia e sismologia regionais de interesse às usinas nucleares da Praia de Itaorna. IPT, Monografias (6), 159 p., São Paulo.

KOWSMANN, R. O. \& COSTA, M. P. A. 1979. Sedimentação quaternária da margem continental brasileira e das áreas oceânicas adjacentes. Série Projeto Remac (8), Petrobrás-CENPES.

LAUAR, C.R.M. 1988. Estudo paleomagnético dos maciços alcalinos de Poços de Caldas, Passa Quatro e Itatiaia. Dissertação de mestrado, IAG - USP, $101 \mathrm{p}$.

LEFÈVRE, M.A. 1957. Observations morphologiques dans les Massifs de Serra do Mar et de l'Itatiaia. Zeitsch. Geomorph. 1(3):302-308.

LEHMAN, H. 1960. Observações morfoclimáticas na Serra da Mantiqueira e no vale do Paraíba. Not. Geomorf. 3(5):1-5.

MACAR, P. 1957. Notes sur l'excursion a l'Itatiaia. (Brésil, 1956). Zeitsch. Geomorph. 1(3):293-296.

MODENESI, M. C. 1980. Intemperismo e morfogênese no Planalto de Campos do Jordão, São Paulo. Revista Brasileira de Geociências. 10(3)213-225. 
MODENESI, M. C. 1984. Evolução Quaternária de uma montanha tropical: o planalto de Campos do Jordão, São Paulo. Revista do Instituto Geológico. 5(1/2):7-13.

1988. Significado dos Depósitos Correlativos Quaternários em Campos do Jordão-São Paulo: implicações paleoclimáticas e paleoecológicas. Boletim, Instituto Geológico n? 7, 155 p. 1988a. Quaternary Mass Movements in a Tropical Plateau (Campos do Jordão, São Paulo, Brazil). Zeitsch. Geomorph. 32(4):425-440.

1989. Hillslope Forms and Quaternary Deposits in the Itatiaia Plateau - RJ - Brazil. In: International Symposium on Global Changes in South America During the Quaternary, Special Publication (1):293-300.

\& MELHEM, T.S. 1986. Primeiros resultados da palinologia dos sedimentos turfosos da várzea do Ribeirão das Flores, Itatiaia-RJ. Revista do Instituto Geológico. 7(1/2):35-38.

MORTENSEN, H. 1962. Sobre algumas formas de superfície ao norte do Rio de Janeiro, na Serra do Mar e na Serra do Itatiaia. Not. Geomorf. 9/10. 54-58.

ODMAN, O. H. 1955. On the presumed glaciation in the Itatiaia Mountains, Brazil. Eng. Miner. Metalurgia, 21(123):107-108.

PELTIER, L. C. 1950. The geographic cycle in periglacial regions as it is related to climatic geomorphology. Ann. Assoc. Amer. Geogr., 40:214-236.

PENALVA, F. 1967. Geologia e Tectônica da Região do Itatiaia (Sudeste do Brasil) F.F.C.L. - USP Bol. (302) - Geol. (22)95-106.

PO-SHENG, C. 1968. Relationship of block faulting to stream development on both flanks of Chin-Ling Mountain Region. Intern. Geol. Review 10(12):1428-1439.

POTTS, A. S. 1970. Frost action in rocks: some experimental data. Transactions of the Institute of British Geographers, 49:109-124.
RAYNAL, R. 1957. Les formations de versants et l'évolution climatique dans la Serra Mantiqueira. Zeitsch. Geomorph. 1(3):279-289. 1957a. Vallée du Paraíba, Serra da Mantiqueira et région de São Paulo. Ann. Géogr. 66(353):51-66.

RIBEIRO FILHO, E. 1967. Geologia e Petrologia dos maciços alcalinos do Itatiaia e Passa Quatro. F.F.C.L. - USP, Bol. (302), Geologia (22):5-93.

RICCOMINI, C. 1989. O rift continental do sudeste do Brasil. Tese de doutoramento. Instituto de Geociências - USP.

$$
\text { ; PELlOGIA, A.U.G; SALONI, }
$$
J.C.L.; KOHNKE, M.W \& FIGUEIRA, R.M. 1989. Neotectonic activity in the Serra do Mar Rift System (Southeastern Brazil) Journal South American Earth Science 2(2):191-197.

RICH, J.L. 1953. Problems in Brazilian Geology and Geomorphology suggested by reconaissance in summer of 1951. Bol. F.F.C.L. - USP. (146) Geol.(9), 80 p.

RUELLAN, F. 1943. Comunicação sobre a excursão a Campo Belo e Itatiaia. Bol. Geogr. 1(7):76-80.

SEGADAS-VIANA, F. 1965. Ecology of the Itatiaia Range, Southeastern Brazil. Arquivo Museu Nacional. 53:7-53.

SELBY, M.J. 1982. Hillslope Materials and Processes. Oxford University Press, 264 p., New York.

SHEPARD, F.P. 1954. Nomenclature based on sand-silt-clay ratios. Journal of Sedim. Petrol. 24(3)151-158.

SILVEIRA, J.D. 1942. Itatiaia. Anais IX Congresso Brasileiro de Geografia - Rio de Janeiro, vol. II, p. 707-720.

TRICART, J. 1956. Étude experimentale du probléme de la gélivation. Biuletyn Peryglacialny, 4:285-318.

VALVERDE, O. 1952. Guia de excursão ao Itatiaia pelos membros da XII Assembléia Geral do CNG. Rio de Janeiro.

Endereço da autora:

May Christine Modenesi - Instituto Geológico - SMA - Caixa Postal 8772 - 04301-903 - São Paulo, SP - Brasil. 